\title{
Milk productivity of black-and-white and Kholmogory cows with different genotypes of kappa-casein
}

\author{
Radik Shaidullin ${ }^{1 *}$, Lenar Zagidullin ${ }^{2}$, Anastasia Moskvicheva ${ }^{1}$, Rifat Khisamov ${ }^{2}$ and Tahir Akhmetov ${ }^{2}$ \\ ${ }^{1}$ Kazan State Agrarian University, Kazan 420015, Russia \\ 2 Kazan State Academy of Veterinary Medicine named after N.E. Bauman, Kazan, 420029, Russia
}

\begin{abstract}
The influence of genotypes for kappa-casein gene on the main indicators of milk productivity in the 1st and 3rd lactation in black-and-white and Kholmogory cows was studied. The genotyping of cows for the CSN3 gene was carried out by the method of DNA diagnostics. Cows of the black-and-white breed with genotype $C S N 3 B B$ surpass the group with genotype $C S N 3 A A$ and $C S N 3 A B$ in the 1st lactation in milk yield by $166-218$ and in milk fat yield by $4.9-8.7 \mathrm{~kg}$; for the 3rd lactation $188-298 \mathrm{~kg}$ and $7.7-10.2 \mathrm{~kg}$, respectively. At the same time the difference is significant in terms of the mass fraction of protein in milk by $0.06-0.15 \%(\mathrm{P}<0.05-0.001)$ and $0.11-0.15 \%(\mathrm{P}<0.001)$ and in the yield of milk protein $(\mathrm{P}<0.05) 8.3-14.2$ $\mathrm{kg}$ and $14.8-16.1 \mathrm{~kg}(\mathrm{P}<0.05)$. Kholmogory cows have a similar advantage for cattle with genotypes CSN3 $A A$ and $C S N 3 A B$ in terms of milk productivity with a significant excess in the mass fraction of protein in milk for the 1 st lactation by $0.07-0.14 \%$ ( $\mathrm{P}<0.05-0.001$ ), for the 3rd lactation by $0.08-0.11 \%(\mathrm{P}<0.05$ 0.001 ). Consequently, the black-and-white and Kholmogory breeds have approximately the same level of superiority of cows homozygous for $B$ allele CSN3 over their herdmates.
\end{abstract}

\section{Introduction}

The milk productivity of cows is the main indicator by which the selection of dairy breed cattle is carried out.

Polymorphic proteins are an important part of milk protein, studies on their effect on milk protein in general are being carried out, and differences have been identified between livestock that have different genetic protein types. From this perspective, the dependence of milk productivity on the genotype of the cow and the possibility of using genetic types of markers in breeding cattle have been determined [1-3].

The kappa-casein gene (CSN3) has been the most studied gene by Russian and foreign scientists among the genetic markers of productivity. According to some sources, an increase in milk productivity among cows of the Kholmogory breed was noted in individuals with the $A A$ genotype for the $C S N 3$ gene. In terms of the mass fraction of protein in milk, the highest indicators were observed in animals with genotypes $A B$ and $B B$ [4]. Similar studies of the Kholmogory population showed that individuals with the $\operatorname{CSN} 3 A A$ genotype were superior to their counterparts with the $C S N 3 B B$ genotype in milk yield and the amount of milk protein, but at the same time, they were inferior in terms of the mass fraction of fat in milk [5].

Butterfat percentage and milk protein content in cows with the CSN3 $A B$ genotype are higher than in herdmates with the CSN3 AA genotype [6].

As was mentioned above, the indicators of milk productivity of cows to a certain extent depend on the genotype of animals for genes encoding the synthesis of the main components of milk. But in different dairy cattle breeds this dependence manifests itself in different ways, and the ascertaining of an association of milk productivity with the genotype of kappacasein in dairy cattle of different origin and breeds is up to date.

The purpose of the research was to study the influence of genotypes for the kappa-casein gene on the main indicators of milk productivity in the 1 st and 3rd lactation in black-and-white and Kholmogory cows.

\footnotetext{
Corresponding author: tppi-kgau@bk.ru
} 


\section{Materials and Methods}

First-calf heifers and full-aged black-andwhite and Kholmogory cows, from which blood samples were taken and DNA samples were isolated, were selected for research in the conditions of the breeding reproducer of OOO «Dusym» (Dusym,LLC) of Atninsky District and OAO «Plemzavod Biryulinsky» (Plemzavod Biryulinsky, JSC) in Vysokogorsky District of the Republic of Tatarstan.

The material for DNA testing was venous blood of experimental animals. DNA was isolated from each blood sample using the kit "Magnosorb" (Interlabservis, Moscow, Russia) according to the manufacturer's instructions. The CSN3 gene was studied by polymerase chain reaction method followed by analysis of restriction fragment length on polymorphism (PCR-RFLP) using the forward primer 5'TAGCCAAATATATCCCAATTCAGT-3' and reverse primer 5'TTTATTAATAAGTCCATGAATCTTG -3 [7]. Amplification with primers was performed by amplifier "Tertsik" ("DNA technology", Moscow, Russia) according to standard practice. It was used as the PCR mixture of the following composition: a pair of primers for amplification of the studied gene, a mixture of nucleoside triphosphates (2.5 $\mathrm{mM})$, magnesium chloride (25m $)$, tenfold PCR buffer, Taq polymerase.

The derived amplicons were exposed to restriction using restriction enzymes Hinf $I$ (CSN3 gene) (SibEnzyme, Russia) according to the manufacturer's recommendations. After hydrolysis, the amplicon fragments were exposed to horizontal electrophoresis in a $2.5 \%$ agarose gel.

Depending on the presence of alleles A and $\mathrm{B}$ of $C S N 3$ gene, genotypes were divided into three groups $(A A, A B, B B)$. Data on milk production of cows with different CSN3 genotypes were used for the research.

The economic efficiency of milk production from cows with different genotypes was determined according to the "Methodological recommendations for determining the economic efficiency from the implementation of the results of the research in animal breeding" [8]. The amount of milk in terms of the all-
Russian basic norm of the mass fraction of protein and fat was determined by the formula:

$$
W_{f p}=\frac{W_{a v} \times F_{a v} \times P_{a v}}{F_{b} \times P_{b}},
$$

where $\mathrm{W}_{\mathrm{fp}}$ - conventional value of net content weight of raw milk, $\mathrm{kg}$;

$\mathrm{Wav}_{\mathrm{av}}$ - actual value of net content weight of raw milk, $\mathrm{kg}$;

$\mathrm{F}_{\mathrm{av}}$ - actual value of mass fraction of fat, \%;

$\mathrm{Pav}_{\mathrm{av}}$ - actual value of the mass fraction of protein, \%;

$\mathrm{Fb}$ - basic all-Russian norm of mass fraction of fat, $\%$;

$\mathrm{Pb}-$ basic all-Russian norm of protein mass fraction, $\%$.

The obtained materials were statistically processed using the Microsoft Excel software from the Microsoft Office 2007 software package.

The materials were statistically processed followed by the calculation of the arithmetic mean (M) and arithmetic mean error (m) in the Microsoft Excel 2007 software application. The level of reliability of the results was determined by the Student's criterion.

\section{Results}

As a result of the carried out studies on polymorphism of kappa-casein gene in dairy cattle, the following data were obtained. $67 \%$ (101 cows) have the $A A$ genotype of kappa-casein gene from the selected 151 first-calf cows of the black-and-white breed, 29\% (44 cows) have the $C S N 3 A B$ genotype (44 cows), and only $4 \%$ (6 cows) have the $C S N 3 B B$ genotype (table 1), while the frequency of allele $A$ was 0.81 , and allele $B$ was 0.19 .

In the group of full-grown cows 109 cows were identified with the CSN3 $A A$ genotype, 52 cows were with the heterozygous $C S N 3 A B$ genotype, and only 7 cows were with the desired homozygous $C S N 3 B B$ genotype. The frequency of genotypes reached: $A A-$ $65 \%, A B-31 \%, B B-4 \%$. However, the frequency of allele $A$ was 0.80 and the frequency of the desired allele $B$ was 0.20 .

The milk yield per lactation was higher in the firstcalf heifers of the black-and-white breed with $C S N 3 B B$ genotype in comparison with $C S N 3 A A$ animals by 218 $\mathrm{kg}$ and $C S N 3 A B$ genotype by $166 \mathrm{~kg}$. The amount of milk fat and protein increased by $8.7 \mathrm{~kg}, 4.9 \mathrm{~kg}$ and 14.2 $\mathrm{kg}, 8.3 \mathrm{~kg}$, respectively (table 2), while the difference is significant only in the yield of milk protein $(\mathrm{P}<0.05)$.

The animals with the desired allele $B$ of kappa-casein significantly exceeded the CSN3 $A A$ group in terms of the mass fraction of protein in milk by $0.06-0.15 \%(\mathrm{P}$ $<0.05-0.001)$. A significant difference was also noted between the $C S N 3 A B$ and $C S N 3$ $A A$ groups in favor of heterozygous firstcalf heifers, that was $0.09 \%(\mathrm{P}<0.001)$. 
The animals with the $C S N 3 A B$ genotype had the mass fraction of fat in milk $3.79 \%$, which was $0.03 \%$ higher than in cows with the CSN3 $B B$ genotype and significantly higher than in first-calf heifers with the CSN3 AA genotype by $0.04 \%(\mathrm{P}<0.05)$.

As for full-grown cows, the advantage of animals with the $B$ allele of the kappacasein locus in their genome was also noted. Thus, cows with genotype $C S N 3 B B$ surpass the group with genotype $C S N 3 A A$ by $188 \mathrm{~kg}$ in milk yield, $C S N 3 A B$ - by 298 $\mathrm{kg}$; by the yield of milk fat - by $7.7 \mathrm{~kg}$ and $10.2 \mathrm{~kg}$. By mass fraction of protein it was by $0.15 \%(\mathrm{P}<0.001)$ and $0.11 \%(\mathrm{P}<0.001)$; by the yield of milk protein - by $14.8 \mathrm{~kg}$ and $16.1 \mathrm{~kg}(\mathrm{P}<0.05)$, respectively.

The best butterfat percentage was noted in heterozygous cows that was $3.80 \%$, exceeding other groups by $0.02-0.03 \%$.

Consequently, it was revealed that the highest milk productivity in black-and-white cattle is characteristic of cows with allelic variants $A B$ and $B B$ of the kappa-casein gene, irrespective of age.

Our data conform to the studies of F.F. Zinnatova et al. (2010) and Shaydullina R.R. et al. (2015), according to which there is an advantage in milk productivity in black-and-white cattle with the $B$ allele of kappa-casein [9-10].

Among cows of Kholmogory breed, CSN3 AA genotype was identified in $64-65 \% ; 31-33 \%$ had $C S N 3$ $A B$ genotype, and $4 \%$ had the most desirable $C S N 3 B B$ genotype (table 3 ). The frequency of $A$ allele was 0.80 , and $B$ allele was 0.20 .

Kholmogory first-calf heifers with genotype CSN3 $A B$ are characterized by high milk productivity and surpass other groups in milk yield by $118-164 \mathrm{~kg}$, in fat mass fraction in milk by $0.01-0.04 \%$, in milk fat yield by $5.1-8.4 \mathrm{~kg}$, according to the yield of milk protein by $0.4-$ $8.8 \mathrm{~kg}$ (table 4).
The cows with the $C S N 3 B B$ genotype have an advantage in terms of the mass fraction of protein in milk by $0.07-0.14 \%$ ( $\mathrm{P}<0.05-0.001)$.

Full-grown cows with genotype $C S N 3 B B$ have an advantage in milk yield by $79-100 \mathrm{~kg}$, in the amount of milk fat by $1.9-5.0 \mathrm{~kg}$, in the amount of milk protein by $7.3-9.8 \mathrm{~kg}$, the mass fraction of protein in milk - by 0.08 $0.11 \%(\mathrm{P}<0.05-0.001)$.

Thus, it is necessary to identify dairy cattle with genotypes $C S N 3 A B$ and $C S N 3 B B$ to conduct a homogeneous selection of parental pairs and selection for breeding animals with the allelic variant $B$ of kappacasein in the genotype.

Similar results were obtained in the studies of Sh.K. Shakirov, Yu.R. Yulmetyeva, F.F. Zinnatova (2012), who noted an increase in milk yield, milk fat and protein yield in animals of the Kholmogory breed with the $B$ allele in the genome of kappa-casein of CSN3 gene [11].

It should be noted that animals of the analyzed groups, regardless of breed and age, carrying the allele $B$ of kappa-casein in their genome, have an increased butterfat percentage and milk protein content. Similar results on obtaining high milk yields and higher milk protein from cows of various breeds with the $B$ allele of kappa-casein in the genotype were found in both domestic [12-14] and foreign cattle [15-17].

In dairy farming the efficiency of production is an important issue that is mainly determined by the level of milk productivity of cows and the selling price of a unit of dairy products. The higher the productivity of animals and the purchase price of milk, the lower the cost per unit of manufactured products and the higher the profit from sales. Taking this into account, an analysis of the economic efficiency of milk production from black-and-white and Kholmogory cows with different genotypes of kappa-casein was carried out.

Table 1. Frequency of occurrence of genotypes and alleles of kappa-casein gene in black-and-white cows.

\begin{tabular}{|c|c|c|c|c|c|c|c|c|c|}
\hline \multirow{2}{*}{\multicolumn{2}{|c|}{ Total livestock }} & \multicolumn{6}{|c|}{ Genotype frequency, \% } & \multirow{2}{*}{\multicolumn{2}{|c|}{ Allele frequency }} \\
\hline & & \multicolumn{2}{|c|}{$\square \square$} & \multicolumn{2}{|c|}{$\nabla \square$} & \multicolumn{2}{|c|}{$\square \square$} & & \\
\hline $\mathrm{n}$ & $\%$ & $\mathrm{n}$ & $\%$ & $\mathrm{n}$ & $\%$ & $\mathrm{n}$ & $\%$ & $\square$ & $\square$ \\
\hline \multicolumn{10}{|c|}{ 1st lactation } \\
\hline 151 & 100 & 101 & 67 & 44 & 29 & 6 & 4 & 0.81 & 0.19 \\
\hline \multicolumn{10}{|c|}{ 3rd lactation } \\
\hline 168 & 100 & 109 & 65 & 52 & 31 & 7 & 4 & 0.80 & 0.20 \\
\hline
\end{tabular}

Table 2. Milk productivity of cows in the 1st and 3rd lactation of black-and-white breed with different genotypes of kappa-casein

\begin{tabular}{|c|c|c|c|}
\hline \multirow{2}{*}{ Indicators } & \multicolumn{3}{|c|}{ CSN3 genotype } \\
\hline & $\square \square$ & $\square \square$ & $\square \square$ \\
\hline \multicolumn{4}{|c|}{ 1st lactation } \\
\hline
\end{tabular}




\begin{tabular}{|c|c|c|c|}
\hline $\mathrm{n}$ & 101 & 44 & 6 \\
\hline Milk yield, $\mathrm{kg}$ & $4593 \pm 38.2$ & $4645 \pm 65.3$ & $4811 \pm 166.5$ \\
\hline Fat, \% & $3.75 \pm 0.010$ & $3.79 \pm 0.016$ & $3.76 \pm 0.021$ \\
\hline Milk fat, kg & $172.2 \pm 1.57$ & $176.0 \pm 2.59$ & $180.9 \pm 5.57$ \\
\hline Protein, \% & $3.18 \pm 0.006$ & $3.27 \pm 0.011$ & $3.33 \pm 0.024$ \\
\hline Milk protein, kg & $146.0 \pm 1.20$ & $151.9 \pm 2.25$ & $160.2 \pm 5.68$ \\
\hline \multicolumn{4}{|c|}{ 3rd lactation } \\
\hline $\mathrm{n}$ & 109 & 52 & 7 \\
\hline Milk yield, kg & $5698 \pm 45.3$ & $5588 \pm 71.1$ & $5886 \pm 151.2$ \\
\hline Fat, \% & $3.77 \pm 0.010$ & $3.80 \pm 0.018$ & $3.78 \pm 0.041$ \\
\hline Milk fat, kg & $214.8 \pm 1.63$ & $212.3 \pm 2.03$ & $222.5 \pm 9.39$ \\
\hline Protein, \% & $3.19 \pm 0.007$ & $3.23 \pm 0.012$ & $3.34 \pm 0.023$ \\
\hline Milk protein, $\mathrm{kg}$ & $181.8 \pm 1.55$ & $180.5 \pm 1.71$ & $196.6 \pm 7.81$ \\
\hline
\end{tabular}

Table 3. Frequency of occurrence of genotypes and alleles of the kappa-casein gene in cows of Kholmogory breed

\begin{tabular}{|c|c|c|c|c|c|c|c|c|c|}
\hline \multirow{2}{*}{\multicolumn{2}{|c|}{ Total livestock }} & \multicolumn{6}{|c|}{ Genotype frequency, \% } & \multirow{2}{*}{\multicolumn{2}{|c|}{ Allele frequency }} \\
\hline & & \multicolumn{2}{|c|}{$\square$} & \multicolumn{2}{|c|}{ प् } & \multicolumn{2}{|c|}{$\Delta \square$} & & \\
\hline $\mathrm{n}$ & $\%$ & $\mathrm{n}$ & $\%$ & $\mathrm{n}$ & $\%$ & $\mathrm{n}$ & $\%$ & $\boldsymbol{\square}$ & $\square$ \\
\hline \multicolumn{10}{|c|}{ 1st lactation } \\
\hline 160 & 100 & 103 & 65 & 50 & 31 & 7 & 4 & 0.80 & 0.20 \\
\hline \multicolumn{10}{|c|}{ 3rd lactation } \\
\hline 143 & 100 & 92 & 64 & 45 & 33 & 6 & 4 & 0.80 & 0.20 \\
\hline
\end{tabular}


Table 4. Milk productivity of cows in the 1st and 3rd lactation of the Kholmogory breed with different genotypes of kappa-casein

\begin{tabular}{|c|c|c|c|}
\hline \multirow[t]{2}{*}{ Indicators } & \multicolumn{3}{|c|}{ CSN3 genotype } \\
\hline & $\square \square$ & $\Delta \square$ & $\square$ \\
\hline \multicolumn{4}{|c|}{ 1st lactation } \\
\hline $\mathrm{n}$ & 103 & 50 & 7 \\
\hline Milk yield, kg & $4946 \pm 64.9$ & $5110 \pm 93.5$ & $4992 \pm 133.2$ \\
\hline Fat, $\%$ & $3.86 \pm 0.019$ & $3.90 \pm 0.026$ & $3.89 \pm 0.034$ \\
\hline Milk fat, $\mathrm{kg}$ & $190.9 \pm 2.89$ & $199.3 \pm 3.96$ & $194.2 \pm 4.43$ \\
\hline Protein, \% & $3.22 \pm 0.006$ & $3.29 \pm 0.013$ & $3.36 \pm 0.033$ \\
\hline Milk protein, kg & $159.3 \pm 2.37$ & $168.1 \pm 3.45$ & $167.7 \pm 4.48$ \\
\hline \multicolumn{4}{|c|}{ 3rd lactation } \\
\hline $\mathrm{n}$ & 92 & 45 & 6 \\
\hline Milk yield, kg & $5791 \pm 47.0$ & $5812 \pm 73.4$ & $5891 \pm 106.8$ \\
\hline Fat, \% & $3.84 \pm 0.014$ & $3.88 \pm 0.018$ & $3.86 \pm 0.033$ \\
\hline Milk fat, $\mathrm{kg}$ & $222.4 \pm 1.77$ & $225.5 \pm 2.03$ & $227.4 \pm 5.62$ \\
\hline Protein, $\%$ & $3.23 \pm 0.007$ & $3.26 \pm 0.011$ & $3.34 \pm 0.028$ \\
\hline Milk protein, kg & $187.0 \pm 1.67$ & $189.5 \pm 1.84$ & $196.8 \pm 4.43$ \\
\hline
\end{tabular}

The economic efficiency of milk production from cows with different genotypes for kappa-casein was calculated for practical assessment of the carried out research. During calculation the indicators of milk productivity of animals and the average selling price of $1 \mathrm{~kg}$ of raw milk were used, while the productivity was recalculated taking into account the basic all-Russian norm of the mass fraction of fat and protein.

During calculation of the economic efficiency of milk production, black-andwhite cows with genotypes $C S N 3 A B$ and $C S N 3 B B$ compared to $C S N 3 A A$ animals produced more milk in the 1 st lactation by $5.1-10.0 \%$ and the 3rd lactation by 0.9 $8.4 \%$, with additional production per head in the amount of 4724-9263 rubles and 1043-9734 rubles (table 5).

Table 5. Efficiency of milk production from black-and-white cows with different genotypes of kappa-casein

\begin{tabular}{|c|c|c|c|c|}
\hline \multirow{2}{*}{\multicolumn{2}{|c|}{ Indicators }} & \multicolumn{3}{|c|}{ Genotype CSN3 } \\
\hline & & $\begin{array}{l}A A \\
\text { (base } \\
\text { case) }\end{array}$ & $A B$ & $B B$ \\
\hline \multicolumn{5}{|c|}{ 1st lactation } \\
\hline \multicolumn{2}{|c|}{$\begin{array}{l}\text { Milk of the basic all-Russian } \\
\text { norm of the mass fraction of } \\
\text { protein and fat was received, } \\
\mathrm{kg}\end{array}$} & 5370 & 5644 & 5906 \\
\hline \multirow{2}{*}{$\begin{array}{l}\text { Increase of the main } \\
\text { products (milk) }\end{array}$} & $\mathrm{kg}$ & - & 274 & 536 \\
\hline & $\%$ & - & 5.1 & 10.0 \\
\hline \multicolumn{2}{|c|}{$\begin{array}{l}\text { Cost of additional products per } \\
\text { head, rubles }\end{array}$} & - & 4724 & 9263 \\
\hline \multicolumn{5}{|c|}{ 3rd lactation } \\
\hline \multicolumn{2}{|c|}{$\begin{array}{l}\text { Milk of the basic all-Russian } \\
\text { norm of the mass fraction of }\end{array}$} & 6718 & 6724 & 7285 \\
\hline
\end{tabular}

\begin{tabular}{l|l|l|c|c|}
\hline \multicolumn{2}{|l|}{$\begin{array}{l}\text { protein and fat was received, } \\
\mathrm{kg}\end{array}$} & & & \\
\hline $\begin{array}{l}\text { Increase of the main } \\
\text { products (milk) }\end{array}$ & $\mathrm{kg}$ & - & 6 & 426 \\
\cline { 2 - 5 } & $\%$ & - & 0.9 & 8.4 \\
\hline $\begin{array}{l}\text { Cost of additional products per } \\
\text { head, rubles }\end{array}$ & - & 1043 & 9734 \\
\hline
\end{tabular}

A similar pattern of higher milk production per head can be observed in Kholmogory cattle with genotypes CSN3 $A B$ and $C S N 3 B B$, for the 1st lactation by $6.1-$ $6.6 \%$ and the 3rd lactation by $2.3-5.7 \%$, also an additional profit from a cow was received in 6342-6862 rubles and 27946924 rubles, respectively (table 6).

When comparing economic indicators in the context of breeds, it was revealed that black-and-white cows with the CSN3 $B B$ genotype exceed their analogues in the 1st lactation by 2921 rubles and the 3rd lactation by 2810 rubles, and Kholmogory cattle with the CSN3 $A B$ genotype have more proceeds in cash per head in the amount of 2138 rubles and 1751 rubles. Therefore, the efficiency of milk production is the best from cows with the $\mathrm{B}$ allele of kappa-casein because it contributes to additional profit from the sale of raw milk.

Table 6. Efficiency of milk production from cows of the Kholmogory breed with different genotypes of kappa-casein

\begin{tabular}{|l|c|c|c|}
\hline \multirow{2}{*}{ Indicators } & \multicolumn{3}{|c|}{ Genotype CSN3 } \\
\cline { 2 - 4 } & $\begin{array}{c}A A \\
\text { (base } \\
\text { case) }\end{array}$ & $A B$ & $B B$ \\
\hline \multicolumn{4}{|c|}{ 1st lactation } \\
\hline $\begin{array}{l}\text { Milk of the basic all- } \\
\text { Russian norm of the mass } \\
\text { fraction of protein and fat }\end{array}$ & 6027 & 6428 & 6397 \\
\hline
\end{tabular}




\begin{tabular}{|l|l|c|c|c|}
\hline \multicolumn{2}{|l|}{ was received, kg } & & & \\
\hline $\begin{array}{l}\text { Increase of the main } \\
\text { products (milk) }\end{array}$ & $\mathrm{kg}$ & - & 401 & 370 \\
\cline { 2 - 5 } & $\%$ & - & 6.6 & 6.1 \\
\hline $\begin{array}{l}\text { Cost of additional products } \\
\text { per head, rubles }\end{array}$ & - & 6862 & 6342 \\
\hline \multicolumn{3}{|l|}{ 3rd lactation } & 7446 \\
\hline $\begin{array}{l}\text { Milk of the basic all- } \\
\text { Russian norm of the mass } \\
\text { fraction of protein and fat } \\
\text { was received, kg }\end{array}$ & 7042 & 7207 & 165 & 404 \\
\hline $\begin{array}{l}\text { Increase of the main } \\
\text { products (milk) }\end{array}$ & $\mathrm{kg}$ & - & 2.3 & 5.7 \\
\cline { 2 - 5 } & $\%$ & - & 2794 & 6924 \\
\hline $\begin{array}{l}\text { Cost of additional products } \\
\text { per head, rubles }\end{array}$ & - & 276 \\
\hline
\end{tabular}

Consequently, selection taking into consideration the genotypes of kappacasein loci will allow one to carry out targeted selection of dairy cattle based on economically important farm characteristics, and thereby to increase the profitability of milk production.

\section{Conclusion}

The cows with kappa-casein genotypes $A B$ and $B B$ have the highest levels of milk production in the 1 st and $3 \mathrm{~d}$ lactation and have the best indicators of the mass fraction of fat and protein.

The black-and-white and Kholmogory breeds have approximately the same level of superiority of cows between the groups with the $B$ allele of the kappa-casein gene.

During production of milk, the largest additional proceeds in cash per head were received from first-calf cows with the CSN3 BB genotype, and it is observed to a greater extent in black-and-white cattle.

\section{References}

1. C.M. Cowan, M.R. Dentine, T. Coule, J. Dairy Sci., 75(4), 1097-1104 (1992).

2. O.G. Loretz, E.V. Matushkina, Agrarian Bulletin of the Urals, 3(121), 23-26 (2014).

3. R.R. Shaidullin, L.R. Zagidullin, F.S. Sibagatullin, T.M. Akhmetov et al., Theoretical and practical aspects of polymorphism of genetic markers and their association with the productivity of dairy cattle (Kazan, 2020).

4. E.O. Krupinin, Sh.K. Shakirov, M.Sh. Tagirov, Far Eastern Agrarian Bulletin, 4(44), 120-125 (2017).

5. Yu. Yulmeteva, Sh. Shakirov, A. Minnakhmetov, N. Fatkhutdinov, Dairy and beef cattle breeding, 7, 23-26 (2013).

6. O. A. Epishko, L.A. Tanana, V.V. Peshko, R.V. Trakhimchik, Collection of scientific papers of the North Caucasian Research Institute, 3(1), 41-46 (2014).

7. L.A. Kalashnikova, I.M. Dunin, V.I. Glazko, N.V. Ryzhova, E.P. Golubina, DNA technology for assessing farm animals (Lesnye Polyany: VNIIplem, 1999).

8. Yu.I. Shmakov, A.V. Cherekaev, Methodological recommendations for determining the economic efficiency from the implementation of the results of the research in animal breeding (Moscow, 1984).

9. F.F. Zinnatova, A.M. Alimov, Scientific Notes of Kazan State Academy of Veterinary Medicine, 204, 93-98 (2010).

10. R.R. Shaidullin, A.S. Ganiev, F.S. Sibagatullin, Bulletin of Ulyanovsk State Agricultural Academy, 3(31), 110-115 (2015).

11. Sh.K. Shakirov, Yu.R. Yulmeteva, F.F. Zinnatova, Bulletin of the Russian agricultural science, 5, 6567 (2012).

12. R.V. Tamarova, N.G. Yarlykov, Yu.A. Korchagin, Bulletin of the agro-industrial complex of the Upper Volga region, 2(26), 56-62 (2014).

13. N.O. Telnov, Bulletin of the Ulyanovsk State Agricultural Academy, 2(34), 160-163 (2016).

14. M. Gurses, H. Yuce, E.O. Etem, B. Pater, Animal Production Science, 58(5), 778 (2018).

15. A. Comin, M. Cassandro, S. Chessa, Dairy Sci., 91, 4022-4027 (2008).

16. B.R. Tanaskovska, S. Srbinovska, S. Andonov, S. Trojacanec, T. Nestoriovski, Z.T. International Journal of Agriculture Innovations and Research, 5(12), 266-270 (2016).

17. A. Perna, I. Intaglietta, E. Gambacorta, A. Simonetti, Journal of Dairy Science, 99, 32883294 (2016). 